\title{
LANGUAGE ANXIETY OF ENGLISH AS A FOREIGN LANGUAGE AS PERCEIVED BY LEARNERS IN VOCATIONAL SCHOOL
}

\author{
Agung Ginanjar Anjaniputra \\ Suryakancana University \\ anjaniputragi@gmail.com
}

\begin{abstract}
Given that one of the difficulties in a foreign language acquisition associated with affects is anxiety that is undergone in different circumstances, and may determine the success of acquiring second/foreign languages, this research is aimed at portraying the situations under which learners undergo anxiety in EFL classroom and at exploring how learners cope with their anxiety by involving six students in a vocational school. Under the umbrella of descriptive research, interviews were conducted to collect the data required to address the purposes of this research. The result revealed that the situations under which learners experience language anxiety were categorized into two types of situation that entail performing in front of others and being pointed out by the teacher. Moreover, strategies to cope with the anxiety comprised preparation, positive thinking, and relaxation. Thus, it is suggested that teachers alleviate language anxiety by means of providing sufficient time for preparation, and creating friendlier classroom environment to avoid humiliating learners so that learners' second/foreign language acquisition and learning are optimized.
\end{abstract}

Keywords: language anxiety, second/foreign language acquisition and EFL learners.

\section{INTRODUCTION}

Acquiring more than one languages yields unexpected experiences as it is perceived by learners, and one of the factors determining second/foreign language acquisition is believed to deal with learner characteristics (see Ellis, 1987, 2008; de Bot, Lowie, \& Verspoor, 2005; Gass \& Selinker, 2008). It may be due to the direct interaction between learners and a target language in which they perceive, process, internalize, and later acquire the language. Although intelligence and motivation are deemed the most important predictors of language acquisition (Ellis, 1987), it is asserted that many difficulties in learning a foreign language have been associated with affects or emotions instead of intellect (Murray, Gao, \& Lamb, 2011; Pawlak, 2012, p.157). One of the affects regarding language acquisition is concerned with language anxiety as stated that being capable of coping with this matter can lead to the success of learning and acquiring second or foreign languages (Horwitz, Horwitz, \& Cope, 1986, pp.131-132). Moreover, language anxiety influences learning and 
performance (Suherdi, 2012, p.102), and all people have ever experienced anxiety in different circumstances (ibid. 103). Therefore, in this paper, the portrayal of the situations under which learners undergo anxiety in EFL classroom is going to be investigated.

Second/foreign language acquisition has drawn people's attention for so many years since a lot of people are willing to understand how a second/foreign language can be acquired so that one is able to attain native-like proficiency of the language. Learners have their own experiences in learning a language as their characteristics treasure uniqueness. Some learners may find it easy to acquire the first or native language, but difficult to acquire a second or foreign language, and some other learners acquire both first and second languages effortlessly. This may be because the first and second languages are typologically the same or again learner characteristics play a vital role in this phenomenon. However, in accordance with Linguistic Coding Deficit Hypothesis (LCDH), when learners deal with difficulties in learning a second language, it is likely that the difficulties are affected by their difficulties when learning their first or native language (de Bot et al., 2005). If the hypothesis really exists, it implies that experiences in the acquisition of a first language inevitably contribute to the attainment of a second or foreign language. Thus, anxiety in learning a first language may give impact on anxiety in second language learning.

\section{THEORRETICAL FRAMEWORK}

Anxiety, as it is defined by MacIntyre \& Gardner (1994, p.284, as cited in Onwuegbuzie, Bailey \& Daley, 1999, p.218) is 'the feeling of tension and apprehension specifically associated with second language contexts, including speaking, listening, and learning'. Language anxiety may be experienced by every individual but the distinction lies on the degree of anxiety itself which gives different impacts on individual learners. In regard to it, two dimensions of anxiety shed a light to it, namely facilitating and debilitating anxiety. While the former refers to anxiety that can encourage learners to improve learning achievement, the latter constitutes anxiety resulting in negative trigger in learning and inhibiting achievement (Suherdi, 2012, p.104; Gass \& Selinker, 2012, p.401). Hence, language anxiety may determine the success of acquiring language so that it is important to go about anxiety which stimulates learners to strive for their achievement, not degrading learners' willingness for success. 
Anxiety may emerge as a result of confronting certain situations or being present in any situations learners are exposed to, where these consecutively refer to state anxiety and trait anxiety (Pappamihiel, 2002, p.330; Suherdi, 2012, p.103; Pawlak, 2012, p.173).

Perhaps, as long as language anxiety is concerned, trait anxiety occurs to those who feel anxious in an unthreatening situation such as sitting on the chair in second/foreign language classrooms, and it happens as the class begins up until the end of the meeting. In contrast, state anxiety refers to the sense of anxiety emerging from certain situation as a response to it. So, those who possess state anxiety will feel anxious in specific situation as they feel threatened, for example, presenting before the class, listening to conversation in second/foreign language, asked and pointed by the teacher, etc. It is asserted that being pointed out to perform in English class emerges anxiety for learners (Liu, 2007), and it has negative effect on performance (Thornbury, 2005). Nevertheless, as anxiety may have its facilitating role, language anxiety do not need to be avoided, yet maximized to have learners motivated, and it cannot be denied as one of the factors in acquiring second/foreign language.

When it comes to language anxiety, there must be factors causing learners to undergo such anxiety. The first factor is lack of confidence (Marwan, 2008), as it is also confirmed by the Causal Model (de Bot et al., 2005, p.205) that language anxiety is associated with confidence, and confidence has a correlation with motivation. It is not impossible that once confidence are lacking, language anxiety occurs and demotivates learners. In the meantime, when learners are in a state of high confidence, they hardly experience language anxiety and are surely motivated. Another factor constitutes lack of vocabulary for it is affirmed that vocabulary is one of the aspect which initiates lack of confidence and sense of anxiety (Thornbury, 2005, pp.27-28; Tanveer, 2007, p.3; Liu, 2007, pp.128-129; Indrianty, 2012, p.21). Because of the impact of language anxiety in learning to speak a foreign language (Tanveer, 2007, p.55), it is certainly a problem if learners do not know what words to say.

In addition to the two factors, the third factor has something to do with shyness (Liu, 2007; Indrianty, 2012), relating to the term specifying the situation in which foreign language learners can feel shy, namely communication apprehension defined as "a type of shyness characterized by fear or anxiety about communication with other people" (Horwitz et al., 1986, p.128). The next two factors are likely to be influenced by shyness, which are fear of making mistakes (Liu, 2007; Indrianty, 
2012), and fear of negative evaluation (Tanveer, 2007). Making mistakes is deemed to be something embarrassing by most of learners. It possibly relates to what comes after they make mistake such as negative evaluation, for example correction from other learners where learners making mistakes are mocked and laughed at, or inappropriate feedbacks from teachers. Thus, it should be noted that feedbacks should be delivered properly to ascertain that learners are not demotivated (Brown, 2001; Thornbury, 2005; Harmer, 2007b).

As stated in advance that anxiety may have debilitating effect, it is deemed crucial to provide strategies or techniques to overcome or at least to minimize language anxiety. With regard to the issue, Tanveer (2007, p.55) argues that less formal and friendly environments are required to cope with language anxiety so that learners are encouraged and comfortably engaged in language learning activities. Furthermore, five strategies are proposed to cope with language anxiety, which comprise (1) preparation which is manifested in efforts to control impending threat by means of enhancing learning and learning strategies, (2) relaxation that is typically characterized by taking a deep breath or trying to calm down, (3) positive thinking to create positive, pleasant state of self, (4) peer seeking realized in looking others who have the same problem about language anxiety as comparison, (5) resignation that occurs when anxious learners refuse or become reluctant to do anything (Kondo \& Ying-Ling, 2004, p.262).

Researches on foreign language anxiety have yielded findings that are beneficial for teaching and learning languages, especially for EFL context. These researches focus on the investigation of types of anxiety, what causes anxiety, and how learners cope with their anxiety. For instance, Liu (2007) highlighted some findings that learners felt the most anxious when singled out to perform in front of the class. These senses of anxiety were driven by some factors such as lack of vocabulary, low English proficiency, lack of preparation, lack of practice, fear of making mistakes and being laughed at, fear of losing face, fear of being focus of attention, fear of being unable to follow and understands others, memory disassociation, and inability to express ideas. However, even though learners could identify factors of what made them anxious, they did not have any ideas to overcome their anxiety (Liu, 2007, pp.119-137). Therefore, this research is worth conducting in Indonesian context to understand the situations under which learners feel anxious when learning English. 
Another related research was conducted by Marwan in 2008 within the context of EFL learning in Indonesia, which showed that most foreign language learners experience some kind of foreign language anxiety when learning the language. However, the factors occur differently due to learners' individual differences such as level of English proficiency, gender, attitude toward English, motivation, past experiences and so forth. As it was in line with Liu's findings (2007) about factors triggering language anxiety, the major factors of anxiety highlighted in this research are lack of preparation, lack of confidence, and fear of failing the class (Marwan, 2008, p.119). In regard to the previous related research reports, this research try to qualitatively explore how to cope with their anxiety.

Given the consideration that learners' language anxiety can determine their success of learning as well as acquiring language, and this may also be influenced by circumstances under which learners learn, it comes to a problem of what situations trigger language anxiety as perceived by learners at a vocational school. Hence, considering those explanations above, this study is conducted to portray the situations under which learners experience language anxiety when learning English as a foreign language, and to explore how learners cope with their EFL anxiety.

\section{METHOD}

Having chosen qualitative research design by employing descriptive research, the researcher conducted this research in one of state vocational schools in Cimahi. Qualitative study was selected for this research because it is intended to explore reality about human behaviors within naturally present settings and contexts (Bogdan \& Biklen, 1992; Hatch, 2002), where it bears a resemblance to the purpose of this study to explore the circumstances under which learners experience anxiety and ways of coping with it. The participants involved in this research were six learners comprising 2 high-achievers, 2 mid-achievers, and 2 low-achievers which were chosen based on purposive sampling (Fraenkel and Wallen, 2006, p.101; Creswell, 2007, p.125). Meanwhile, the instrument used to collect the data was interview guideline, administered to the learners in an attempt to portray the conditions under which learners experience language anxiety and how the learners cope with their anxiety in English classroom. 


\section{FINDINGS AND DISCUSSION}

\section{The Situations under Which Learners Undergo EFL Anxiety}

As the data have been analyzed, two categories of situation triggering learners' language anxiety are found. These dealt with performing in front of others and being pointed out by the teacher. Performing in front of others was associated with the situation when learners were asked to present something in English before others, whether it was in the regular class session, in an English course, or in a competition. Meanwhile, being pointed out by the teacher entailed the situation that learners were sometimes singled out for answering questions from the teacher. It appears that, although learners are relaxed and enjoy the English subject, their language anxiety get higher as they are singled out. It is affirmed that language anxiety emerges because of being pointed out to perform in English class (Liu, 2007).

Performing in front of others, as one of the learners stated, makes him shy if what he is saying is wrong. The respondent further expressed that what made him shy was being laughed at by others, as the excerpt shows “...pernah diketawain, jadi malu aja klo bicara di depan orang”. It implies that classroom environment does not seem to encourage and support learners in their learning. It is crucial since once learners feel shy, their confidence may decline as the shyness causing language anxiety is undergone recurrently. It is shown in the Causal Model (de Bot et al., 2005, p.205) that language anxiety is associated with confidence, and confidence has a correlation with motivation. Therefore, it might bring about demotivating condition for learners who are very anxious about speaking in front of others.

Given that the learner was anxious as a result of shyness to speak before others, it suggests the attention the learner pays about others' reaction. It seems that how others perceive the learner's performance affect the learner's feeling and mental processing. In regard to this notion, Suherdi (2012, p.102) states that language anxiety influence learning and performance. Furthermore, it is also argued that anxiety causes negative effect on performance (Thornbury, 2005). In this sense, language anxiety that the learner experienced was generated from his apprehension about how others react to his performance. Tanveer (2007) proposes it as one of the factors triggering language anxiety, namely fear of negative evaluation. Therefore, less formal and friendly environments are required to cope with language anxiety so that learners are encouraged and comfortably engaged in language learning activities (ibid. p.55). 
In addition to performing in front of others, being pointed out by the teacher is said to be another situation that brings about language anxiety. One of the learners stated that the only situation caused anxiety was when the teacher pointed her to answer a question. Besides, it is also shown in the following excerpt uttered by another learner, "kaya klo misalnya kaya belajar di sekolah itu gak bisa, nah itu teh jadi gak pede. Jadi ntar tuh klo misalnya ditanya teh jadinya teh cemas sama takut salah". In classroom settings, questions addressed by a teacher is hardly avoided. Moreover, it was also argued that, in such a situation, the learner used to answer the question carelessly, regardless of whether or not the answer was correct. However, it is a good thing that the anxiety did not lead him to being reluctant to answer the question.

From the evidence, it is clear that why the learner did not like being pointed out was because he had a fear of making mistakes. So, it shows that fear of making mistakes is the triggering factor of language anxiety (Liu, 2007; Indrianty, 2012) in a situation that the learners are being pointed out by the teacher. It can hinder learner developmental process of learning. Learners are likely to withdraw in learning process as a way to avoid making mistakes. Mistakes are not the thing they need to avoid. Mistakes are important to enable them to be aware of the correct one. Actually, it is a common circumstance that they make mistakes in the process of learning because everyone makes mistakes when learning. However, making mistakes is deemed to be something embarrassing by most of learners. Hence, when learners make mistakes, it should be noted that feedbacks are delivered properly to ascertain that learners are not demotivated (Brown, 2001; Thornbury, 2005; Harmer, 2007b).

Above all, it yields that language anxiety experienced by the learners is state anxiety since none of them feel anxious about English classroom all the time, yet in certain situations. State anxiety refers to the sense of anxiety emerging from certain situation as a response to it (Pappamihiel, 2002, p.330; Suherdi, 2012, p.103; Pawlak, 2012, p.173). The learners' anxiety in this research conforms to state anxiety because the learners undergo anxiety in specific situations which comprise performing in front of others and being pointed out by the teacher.

\section{Strategies to cope with EFL anxiety}


As the situations leading to language anxiety were identified, strategies to cope with the anxiety were also found in this research. This finding is in contrast to Liu's finding (2007) concerning ways of overcoming language anxiety, which is asserted that even though learners could identify factors of what made them anxious, they did not have any ideas to overcome their anxiety. However, the finding of this research vis-avis strategies to overcome language anxiety is in line with Kondo \& Ying-Ling (2004) that preparation, positive thinking, and relaxation are strategies to cope with language anxiety. The three strategies are going to be discussed in the following paragraphs.

Preparation has a good contribution to overcome language anxiety. It was expressed by a learner that anxiety was not experienced if preparation was done beforehand so that the learner were ready for and capable of encounter the tasks. Preparation is manifested in efforts to control impending threat by means of enhancing learning and learning strategies (Kondo \& Ying-Ling, 2004, p.262). Because of preparation, the learner feel safe and secured so that he is able to perform without the anxiety, as shown in the following excerpt, "santai kan ngapalin dulu". It confirms that preparation can minimize and perhaps alleviate language anxiety. Considering that being capable of coping with language anxiety can lead to the success of learning and acquiring second or foreign languages (Horwitz et al., 1986, pp.131-132), the learners who do much preparation have an opportunity to be successful in acquiring foreign language as preparation can overcome language anxiety. Therefore, time investment of learners for preparation are the key to this matter.

In addition, positive thinking is one of the strategies learners apply to cope with anxiety. It is intended to create positive, pleasant state of self (Kondo \& Ying-Ling, 2004, p.262). In spite of the advantage of positive thinking, a learner expressed that it was hard to think positively when undergoing language anxiety so that the learner was demotivated and refused to do the practice. It constitutes debilitating anxiety as it results in negative trigger in learning and inhibiting achievement (Suherdi, 2012, p.104; Gass \& Selinker, 2012, p.401). Nonetheless, the demotivating condition could be overcome as the learner thought positively. She thought that she must be able to do that as others were. It is presented in the excerpt “...kadang-kadang kita juga acuannya dari temen kan, ih temen aja bisa gitu, kan kaya gitu masa kita enggak". It can be seen that as the learner thought positively, their confidence become higher and higher. Marwan (2008) argues that lack of confidence is one of the factors of language anxiety, so it is 
worth thinking positively to improve our confidence which in turn overcome language anxiety.

The last, but not the least, is relaxation generally characterized by taking a deep breath or trying to calm down (Kondo \& Ying-Ling, 2004, p.262). What one of the learners do was solely to relax as shown in the following excerpt "oh itu mah saya berusaha, apa berusaha apa namanya tuh, tenang aja gitu. Coba tenang aja". It implies that language anxiety are likely to be overcome by our own self who have a strong desire to have it alleviated. The learner can control his anxiety, and interestingly, the anxiety do not inhibit him from maintaining his spirit. Instead of demotivating, the anxiety is said to be motivating for him when asked about the effect of his anxiety. This has to do with facilitating anxiety that can encourage learners to improve learning achievement (Suherdi, 2012, p.104; Gass \& Selinker, 2012, p.401). Hence, the three strategies can be beneficial for learners in an attempt to cope with language anxiety as long as second/foreign language acquisition is concerned.

\section{CONCLUSION}

To conclude, the situations under which learners undergo EFL anxiety are divided into two major categories, when performing in front of others and when being pointed out by the teacher. In the meantime, ways of how to cope with EFL anxiety comprise positive thinking, preparation, and relaxation. Therefore, teachers can alleviate language anxiety by means of providing learners with sufficient time for preparation as well as for being calm, and creating friendlier environment in the classroom to avoid humiliating learners in order to optimize learners' second/foreign language acquisition and learning.

\section{REFERENCES}

Bogdan, R.C. \& Biklen, S. K. (1992). Qualitative Research for Education: An Introduction to Theory and Methods, 2nd ed.. Boston: Allyn and Bacon.

Creswell, John W. (2007). Qualitative Inquiry and Research Design: Choosing Among Five Approaches $2^{\text {nd }}$ ed.. California: SAGE Publications.

de Bot, K., Lowie, W. \& Verspoor, M. (2005). Second Language Acquisition: An Advance Resource book. New York: Routledge.

Ellis, R. (1987). Understanding Second Language Acquisition. Oxford: Oxford University Press. 
Ellis, R. (2008). Second Language Acquisition. Hong Kong: Oxford University Press.

Fraenkel, J. K. and Wallen, N. E. (2006). How to Design and Evaluate Research in Education, $6^{\text {th }}$ ed.. New York: McGraw Hill.

Gass, S.M. And Selinker, L. (2008). Second Language Acquisition: An Introductory Course, $3^{\text {rd }}$ ed.. New York: Routledge.

Hatch, J. A. (2002). Doing Qualitative Research in Education Settings. New York: State University of New York Press.

Horwitz, E.K., Horwitz, M.B. \& Cope, J. (1986). Foreign Language Classroom Anxiety. The Modern Language Journal, 70 (2), pp.125-132. Retrieved from http://hyxy.nankai.edu.cn/jingpinke/buchongyuedu/foreign\%20language\%20class room\%20anxiety.pdf

Indrianty, S. (2012). Students' Anxiety in Speaking English: A Case Study in Hospitality and Tourism College in Bandung. (Thesis, Universitas Pendidikan Indonesia, 2012, Tidak diterbitkan).

Kondo, D.S., \& Ying-Ling, Y. (2004). Strategies for coping with language anxiety: the case of students of English in Japan. ELT Journal, 58(3), pp.258-265. Retrieved from http://203.72.145.166/ELT/files/58-3-5.pdf

Liu, M. (2007). Indonesian Journal of English Language Teaching. Anxiety in Oral English Classrooms: A Case Study in China. 3 (1), pp.119-137.

Marwan, A. (2008). TEFLIN. The Exploration of Factors Triggering Foreign Language Anxiety: Learners'Voice, 19 (2), pp.119-126.

Murray, G., Gao, X. A. \& Lamb, T. (2011). Identity, Motivation and Autonomy in Language Learning. Bristol: Multilingual Matters.

Onwuegbuzie, A. J., Bailey, P. \& Daley, C. E. (1999). Applied Psycholinguistics. Factors associated with foreign language anxiety, 20 (2), pp.217-239.

Pappamihiel, N. E. (2002). Research in the Teaching of English. English as a Second Language Students and English Language Anxiety: Issues in the Mainstream Classroom, 20, pp.327-355. Retrieved from http://lchc.ucsd.edu/mca/Mail/ xmcamail.2004_09.dir/att-0070/01-RT0363English.pdf [November 21, 2013]

Pawlak, M. (eds.). (2012). New Perspective on Individual Differences in Language Teaching and Learning. Heidelberg: Springer.

Suherdi, D. (2012). Rekonstruksi Pendidikan Bahasa: Sebuah Keniscayaan bagi Keunggulan Bangsa. Bandung: CELTICS Press.

Brown, H.D. (2001). Teaching by Principles: An Interactive Approach to Language Pedagogy $\left(2^{\text {nd }}\right.$ ed.). Ney York: Adison Wesley Longman, inc.

Harmer. J. (2007b). How to Teach English, $2^{\text {nd }}$ ed. UK: Pearson Education Limited. 
Tanveer, M. (2007). Investigation of the Factor that Cause Language Anxiety for ESL/EFL Learners in Learning Speaking Skills and the Influence It Casts on Communication in the Target Language. (Doctoral Dissertation, University of Glasgow, Unpublished) retrieved from http://asian-efljournal.com/thesis_M_Tanveer.pdf [November 27, 2013]

Thornbury, S. (2005). How to Teach Speaking. England: Pearson Educational Limited. 